IZA DP No. 8316

Life Cycle Earnings, Education Premiums and Internal Rates of Return

Manudeep Bhuller

Magne Mogstad

Kjell G. Salvanes

July 2014 


\title{
Life Cycle Earnings, Education Premiums and Internal Rates of Return
}

\author{
Manudeep Bhuller \\ Statistics Norway (SSB) \\ Magne Mogstad \\ University of Chicago, \\ Statistics Norway (SSB), NBER and IZA \\ Kjell G. Salvanes \\ Norwegian School of Economics \\ and IZA \\ Discussion Paper No. 8316 \\ July 2014 \\ IZA \\ P.O. Box 7240 \\ 53072 Bonn \\ Germany \\ Phone: +49-228-3894-0 \\ Fax: +49-228-3894-180 \\ E-mail: iza@iza.org
}

Any opinions expressed here are those of the author(s) and not those of IZA. Research published in this series may include views on policy, but the institute itself takes no institutional policy positions. The IZA research network is committed to the IZA Guiding Principles of Research Integrity.

The Institute for the Study of Labor (IZA) in Bonn is a local and virtual international research center and a place of communication between science, politics and business. IZA is an independent nonprofit organization supported by Deutsche Post Foundation. The center is associated with the University of Bonn and offers a stimulating research environment through its international network, workshops and conferences, data service, project support, research visits and doctoral program. IZA engages in (i) original and internationally competitive research in all fields of labor economics, (ii) development of policy concepts, and (iii) dissemination of research results and concepts to the interested public.

IZA Discussion Papers often represent preliminary work and are circulated to encourage discussion. Citation of such a paper should account for its provisional character. A revised version may be available directly from the author. 


\title{
ABSTRACT
}

\section{Life Cycle Earnings, Education Premiums and Internal Rates of Return*}

\begin{abstract}
What do the education premiums look like over the life cycle? What is the impact of schooling on lifetime earnings? How does the internal rate of return compare with opportunity cost of funds? To what extent do progressive taxes attenuate the incentives to invest in education? This paper exploits Norwegian population panel data with nearly career long earnings histories to answer these important questions. We provide a detailed picture of the causal relationship between schooling and earnings over the life cycle, following individuals over their working lifespan. To account for endogeneity of schooling, we apply three commonly used identification strategies. Our estimates show that additional schooling gives higher lifetime earnings and steeper age-earnings profile, in line with predictions from human capital theory. These estimates imply an internal rate of return of around 10 percent, after taking into account income taxes and earnings-related pension entitlements. Under standard conditions, this finding suggests it was financially profitable to take additional schooling because the rates of return were substantially higher than the market interest rates. By comparison, Mincer regressions understate substantially the rates of return. We explore the reasons for this downward bias, finding that it is driven by Mincer's assumptions of no earnings while in school and exogenous post-schooling employment.
\end{abstract}

JEL Classification: J24, J31

Keywords: education premium, internal rate of return, life cycle earnings

Corresponding author:

Kjell G. Salvanes

Department of Economics

Norwegian School of Economics

Helleveien 30

N-5035 Bergen-Sandviken

Norway

E-mail: kjell.salvanes@nhh.no

\footnotetext{
* An earlier but substantially different version of this paper circulated as "Life-Cycle Bias and the Returns to Schooling in Current and Lifetime Earnings", IZA Discussion Paper No. 5188, June 2011. Financial support from the Research Council of Norway (194339) is gratefully acknowledged.
} 


\section{Introduction}

Many empirical papers use cross-section data to estimate a Mincer regression of the following type:

$$
y=\mu_{0}+\mu_{1} S+\mu_{2} X+\mu_{3} X^{2}+\epsilon,
$$

where $y$ is log earnings, $S$ is years of schooling, $X$ is (potential) experience and $\epsilon$ is the error term. ${ }^{1}$ The problem of selection bias can be addressed by controlling for correlated determinants of earnings or with an instrumental variable for schooling. However, it is not clear how the coefficient on schooling should be interpreted. One possibility is to view the Mincer model as a pricing equation for labor market characteristics and interpret $\mu_{1}$ as the growth rate of earnings with schooling (education premium). A more ambitious interpretation is that $\mu_{1}$ gives the discount rate which equates the present value of potential income streams for different schooling levels. This internal rate of return (IRR) is a fundamental economic parameter that is often used to assess private profitability of additional schooling or whether expenditure on education should be increased or decreased.

A number of strong assumptions must hold in order to interpret $\mu_{1}$ as the IRR (see e.g. Heckman et al., 2006, 2008). While many of these assumptions turn out to hold in the data that Mincer (1974) analyzed, they are now at odds with a large body of evidence (Heckman et al., 2006). Even interpreting $\mu_{1}$ as an education premium requires assumptions that no longer receive support in data. In particular, several studies show that wage patterns have changed substantially over time across cohorts (see e.g. MaCurdy and Mroz, 1995, Card and Lemieux, 2001). As a result, cross-sections no longer approximate the life cycle earnings or schooling returns of any particular individual (Heckman et al. 2006). The use of data that follows actual cohorts over the life cycle is therefore essential to accurately measure their true earnings pattern and estimate the education premiums experienced by individuals.

In this paper, we provide a detailed picture of the causal relationship between schooling and earnings over the life cycle, following individuals over their working lifespan. There are a number of key questions addressed. What do the education premiums look like over the life cycle? What is the impact of schooling on lifetime earnings? How does the IRR compare with the market interest rates typically observed? To what extent do progressive taxes attenuate the incentives to invest in education? To investigate these important questions, we exploit a unique source of

\footnotetext{
${ }^{1}$ See the review articles by Card (1999), Harmon et al. (2003), Psacharopoulos and Patrinos (2004), and Heckman et al. (2006).
} 
population panel data containing records for every Norwegian from 1967 to 2010. Our analysis focuses on males. To account for endogeneity of schooling, we apply three identification strategies that are currently in use in the literature: compulsory schooling reform as an instrument for education; controls for ability test scores; and within-twin-pair estimation. Our analysis is explicitly ex post, focusing on the actual returns earned by certain cohorts ${ }^{2}$

We begin by estimating education premiums at each age. We find that additional schooling gives higher lifetime earnings and steeper age-earnings profile, in line with predictions from human capital theory. The age-specific education premiums imply an IRR of around 10 percent, after taking into account income taxes and earningsrelated pension entitlements. Under standard conditions, this finding suggests it was financially profitable to take additional schooling because the rates of return were substantially higher than the market interest rates typically observed.

Our analysis relaxes many of the strong assumptions that are typical in the literature ${ }^{3}$ Importantly, we can estimate education premiums experienced by individuals over their life cycle and the corresponding rates of return, without assuming multiplicative separability between schooling and experience or a stationary environment. Our approach also relaxes Mincer's assumption of no earnings while in school and exogenous post-schooling employment. Unlike most of the literature, our estimated rates of return take into account income taxation and earnings-related pension entitlements.

In the empirical analysis, we expore how the returns to schooling are affected by incorporating these income components and we compare our estimates of IRR to those produced by Mincer regressions. We find that accounting for income taxation reduces the IRR estimates by around 10-15 percent, whereas earnings-related pention entitlements play a minor role for the incentives to invest in education. Our estimates also reveal that Mincer regressions understate substantially the rates of return. When exploring the reasons for this downward bias, our results point to Mincer's assumptions of no earnings while in school and exogenous post-schooling employment. $f^{4}$

\footnotetext{
${ }^{2}$ In studies that aim to explain or forecast schooling choices, the distinction between ex ante and ex post returns to schooling is important (see e.g. Cunha et al. 2005; Heckman et al., 2006. Cunha and Heckman, 2007). For example, ex post returns govern schooling decisions only if cohorts anticipate future changes in skill prices.

3 Heckman et al. (2006, 2008) examine the role of taxes, tuition and a flexible relationship between earnings, schooling, and experience in the estimation of IRR. However, these studies assume that schooling is exogenous and also require a method for extrapolating the earnings function to work experience levels not observed in the data.

${ }^{4}$ Positive earnings while in school is common in many countries. For example, data on college students in the U.S. suggests that many full-time (45 percent) and part-time (83 percent) students
} 
While there is virtually no pecuniary cost of schooling (such as tuition or fees) in Norway, we abstract from any psychic costs of education. Psychic costs could help explaining why not more individuals take additional schooling despite its high estimated financial return (see e.g. Carneiro et al., 2003, Cunha et al., 2005). Alternative explanations include credit market constraints (see e.g. Carneiro and Heckman, 2002, Lochner and Monge-Naranjo, 2011) or uncertainty about future earnings gains from additional schooling (see e.g. Cunha et al., 2005; Heckman et al., 2006).

This paper unfolds as follows. Section 2 describes our data, presents the identification strategies and reports summary statistics. Section 3 presents the estimated education premiums and corresponding rates of returns. Section 4 contrasts our results with estimates from Mincer regressions. Section 5 concludes.

\section{Data and empirical strategy}

\subsection{Data and sample selection}

Our empirical analysis uses several registry databases maintained by Statistics Norway. This allows us to construct a rich longitudinal data set containing records for every Norwegian from 1967 to 2010. The variables captured in this data set include individual demographic information (including sex and age), socio-economic data (such as years of schooling and annual earnings) and ability test scores from military records. The data set includes personal identifiers, allowing us to link children to their parents and siblings. We can also merge the longitudinal data set with census data from 1960. This allows us to measure family background variables, including childhood municipality of residence.

We consider three measures of income. In each year, our measure of (pretax) earnings is the sum of labor income (from wages and self-employment) and work-related cash transfers (such as unemployment benefits and short-term sickness benefits). To take income taxation into account, we use detailed information on the Norwegian tax system for the period 1967-2010. In each year, we measure after-tax income by subtracting taxes (on labor income and work-related cash transfers) from earnings. We also consider a measure of income which takes earnings-related pension entitlements into account. All Norwegians are entitled to public pension upon retirement (in accordance with the Norwegian National Insurance Act). The pension amount depends on an individual's earnings history from age 16 to retirement. For

were employed during college (INCES, 2013). By comparison, time use surveys from the U.S. suggest that 14 percent of high school students were employed while in school (Kalenkoski and Pabilonia. 2012). See also Hotz et al. (2002) and Dustmann and Van Soest (2007). 
every income variable, we measure income at a given age as the annual real income in the corresponding year, adjusted for inflation..$^{5}$

The Norwegian earnings data have several advantages over those available in most other countries. First, there is no attrition from the original sample because of the need to ask permission from individuals to access their tax records. In Norway, these records are in the public domain. Second, our earnings data pertain to all individuals, and not only to jobs covered by social security. Third, we have nearly career-long earnings histories for certain cohorts. And fourth, top-coding is only performed at very high earnings levels. In fact, less than 3 percent of the observations have right-censored earnings in any given year. ${ }^{6}$

Our regressor of interest is the number of years of schooling. To ensure that virtually everyone has completed their education, we will measure schooling at age 40 throughout this paper. Educational attainment is reported by the educational establishments directly to Statistics Norway, thereby minimizing any measurement error due to misreporting.

In the main analysis, we focus on the 1943-1963 cohorts in order to ensure long earnings histories for all individuals. Our analytical sample is restricted to males because of low labor market participation rates for women in the early periods. We exclude immigrants as well as a small number of individuals with missing information on years of schooling or childhood municipality of residence. Applying these restrictions provides us with what we will refer to as the full sample, consisting of 600,679 individuals.

\subsection{Education premiums and rates of return}

We aim to provide a detailed picture of the relationship between schooling and earnings over the life cycle, following individuals over their working lifespan. In the main analysis, we define the potential working lifespan from ages 17 to 62.7 Consider, for now, the simple earnings regression:

$$
Y_{a}=\alpha_{a}+\beta_{a} S+\varepsilon_{a}
$$

where $Y_{a}$ is the annual real earnings at age $a=17, \ldots, 62, S$ is years of schooling,

\footnotetext{
${ }^{5}$ Throughout the paper, all monetary figures are reported in Norwegian Kroner (NOK), and adjusted for inflation to 2010 levels (USD/NOK $\approx 6$ ).

${ }^{6}$ We have also estimated the returns to schooling using a Pareto distribution to simulate earnings above the top-coded threshold. These estimates are very similar to the baseline results and available from the authors upon request.

${ }^{7}$ Although the mandatory retirement age is 67 , about $80 \%$ of Norwegian workers are entitled to receive early retirement benefits beginning at age 62 (Hernaes et al., 2013).
} 
$\beta_{a}$ is the education premium at age $a$ (which may vary among persons) and $\varepsilon_{a}$ is the residual. Equipped with education premiums at every age, we can assess how additional schooling affects earnings over the life cycle and compute the mean education premium in lifetime earnings,

$$
\bar{\beta}=\sum_{a=17}^{62} \frac{\beta_{a}}{62-16} .
$$

The IRR is the discount rate $(\rho)$ that equates the present value of potential income streams for different schooling levels. The IRR can be defined as the solution to the following equation:

$$
\sum_{a=17}^{62} \frac{\beta_{a}}{(1+\rho)^{a-16}}=0 .
$$

Under standard conditions, the IRR can be compared to opportunity cost of funds to determine if it was financially profitable to take additional schooling. The opportunity cost is often proxied by the real interest rate in the market $(r)$. The profitability of investing in education can then be quantified by computing the education premium in the annuity of lifetime earnings,

$$
\tilde{\beta}=\tilde{r} \sum_{a=17}^{62} \frac{\beta_{a}}{(1+r)^{a-16}}
$$

where the constant $\tilde{r}=\frac{r}{1-(1+r)^{-(62-16)}}$. To calculate annuity values, we discount the earnings streams by a real interest rate of 2.3 percent, which corresponds to the average real interest rate on deposits and loans in Norway over the period 1967-2010 (Aaberge et al., 2011).

Figure 1 illustrates the relationship between life cycle earnings, education premiums and IRR. This figure plots the earnings-age profiles for college and high-school educated Norwegian men born in the years 1943-1963. For now, suppose schooling is exogenous and the education premiums are homogenous across individuals. Both earnings profiles display the familiar concave shape documented and analyzed by Mincer (1974), but the college-educated workers experience more rapid earnings growth through most of the life cycle. The college premium at a particular age $\left(\beta_{a}\right)$ is given by the vertical distance between the earnings profiles. The horizontal lines depict the mean lifetime real earnings for college and high school educated. The college premium in mean lifetime earnings $(\bar{\beta})$ is given by the vertical distance between the two horizontal lines. The discount rates that equates the two earnings streams depends on the extent to which college education gives higher lifetime earnings and steeper age-earnings profile. In particular, the IRR increases in $\bar{\beta}$, holding the slope 
of $\beta_{a}$ fixed; and it reduces in the slope of $\beta_{a}$, keeping $\bar{\beta}$ fixed.

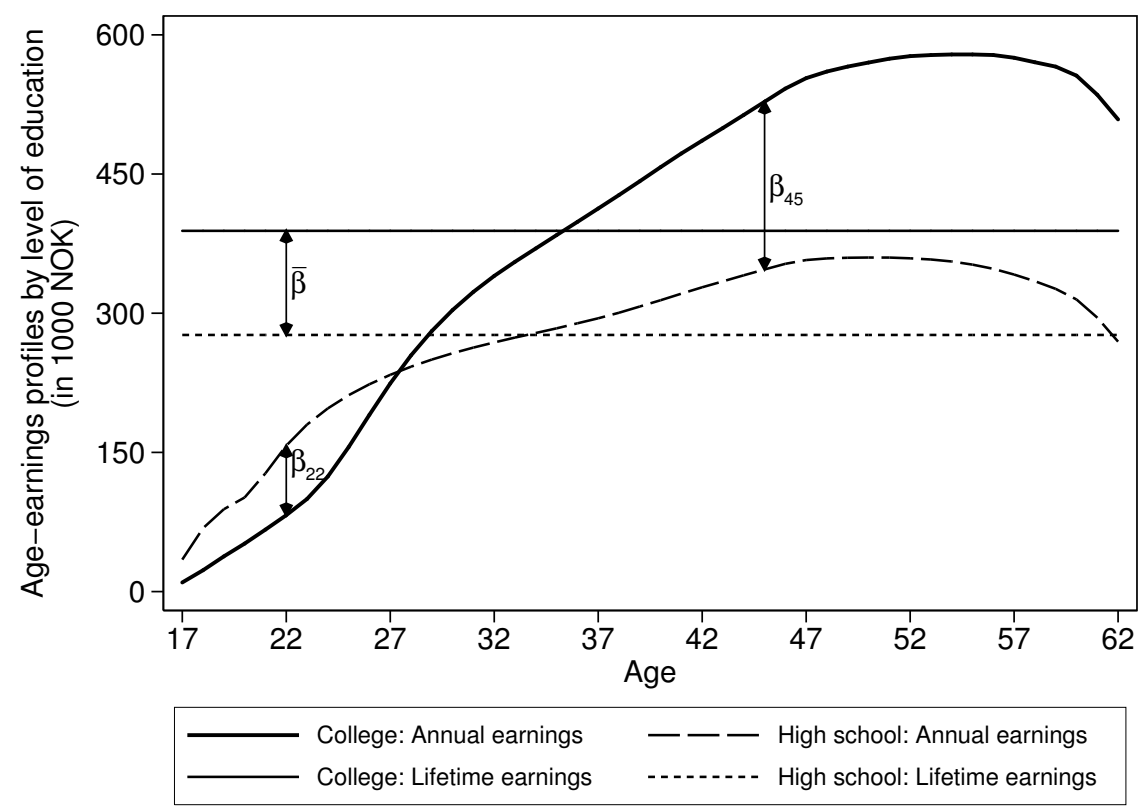

Figure 1. Life cycle earnings and education premiums

Note: We use the full sample, consisting of the 1943-1963 cohorts of males. We graph annual earnings by age and mean lifetime earnings for males with high school diploma (but no post-secondary education) and males with college degree. The college premium at a particular age $\beta_{a}$ is given by the vertical difference between the earnings profiles. The difference between the horizontal lines gives the college premium in mean lifetime earnings, $\bar{\beta}$.

For simplicity, we described here the method for determining the IRR with no income taxation or earnings-related pension. In the empirical analysis, we explore how the results are affected by incorporating these income components and we compare our estimates of IRR to those produced by Mincer regressions.

\subsection{Identification strategies}

In the absence of experimental evidence, it is difficult to know whether the higher earnings observed among highly educated workers are caused by their additional schooling, or whether individuals with greater earnings capacity have chosen to acquire more schooling. To address this concern for selection bias in earnings regressions, a number of identification strategies have been proposed. In this paper, we apply three different identification strategies that are currently in use in the literature.

Instrumental variable approach Our first identification strategy is an instrumental variable (IV) approach that follows Black et al. (2005) in using the staged imple- 
mentation of a Norwegian compulsory schooling law reform as a source of exogenous variation in educational attainment 8

The reform increased compulsory schooling from seven to nine years, and was implemented between 1959 and 1974 in different municipalities (the lowest level of local administration) at different times. Thus, for more than a decade, Norwegian schools were divided into two separate systems, where the length of compulsory schooling depended on the year in which an individual was born and the municipality of residence. From public records, we are able to successfully identify the year in which the reform was implemented for as many as 672 of the 732 municipalities. Individuals who were residing in a municipality to which we could not assign a reform indicator are dropped from our sample. Applying this sample restriction we get an IV sample consisting of 576,704 individuals who were born during the period 1943-1963, covering nearly 96 percent of the full sample. As shown in Appendix Table A.1, there is considerable variation in exposure to the compulsory schooling reform, both across cohorts and municipalities. In particular, nobody born before 1946 was subject to nine years of compulsory schooling, whereas all individuals born after 1960 were affected by the new law.

The IV model is given by the following two-equation system, where (7) is the first stage and $(6)$ is the second stage:

$$
\begin{aligned}
Y_{a} & =\alpha_{a}+\beta_{a} S+\mu_{c a}+\mu_{m a}+e_{a} \\
S & =\gamma_{0}+\gamma_{1} Z+\theta_{c}+\theta_{m}+u
\end{aligned}
$$

where $Z$ is an indicator variable that is equal to 1 if the individual was exposed to the reformed schooling law and 0 otherwise, subscript $m$ denotes municipality and subscript $c$ denotes birth cohort..$^{9}$ Unobservable determinants of earnings or schooling that are fixed at the municipality level will be controlled for through the childhood municipality indicators $\left(\mu_{m a}, \theta_{m}\right)$, just like the birth cohort indicators $\left(\mu_{c a}, \theta_{c}\right)$ absorb changes in cohort quality or aggregate changes in skill prices. Throughout the

\footnotetext{
${ }^{8}$ We refer to Black et al. (2005) for details about the reform. Other studies that have used this reform include Monstad et al. (2008), Aakvik et al. (2010), and Machin et al. (2012). For evidence on how compulsory schooling laws have affected earnings in other countries, see e.g. Angrist and Krueger (1991) and Oreopolous (2006) for the United States, Harmon and Walker (1995), Oreopolous (2006), Devereux and Hart (2010), and Devereux and Fan (2011) for the United Kingdom, Meghir and Palme (2005) for Sweden, and Oreopolous (2006) for Canada and Northern Ireland. None of these studies estimate education premiums experienced by individuals over their life cycle and the corresponding internal rates of return.

${ }^{9}$ Equation (6) specifies a linear relationship between the conditional expectation of earnings $Y_{a}$ and years of schooling $S$. Figure A.1 shows predictions from a local linear regression of schooling on average lifetime earnings. The results suggest that a linear specification provides a fairly good approximation of the underlying earnings-schooling relationship.
} 
paper, standard errors are always clustered at the municipality level and robust to heteroskedasticity.

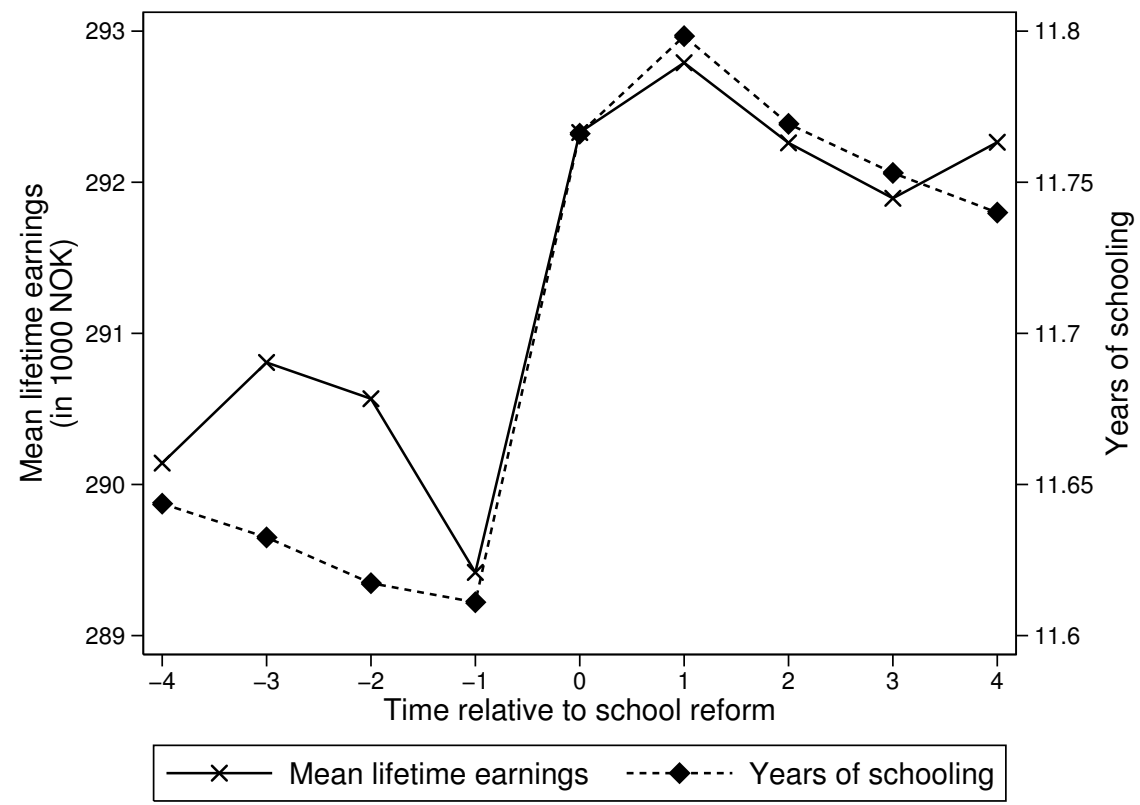

Figure 2. Graphical illustration of the IV approach

Note: For each municipality, we recenter the data such that time zero is the year in which the reform was implemented. Variables are residuals from a regression on birth cohort and municipality fixed effects (adding in a common intercept). We restrict the IV sample to individuals from 660 municipalities (of 672) for which we can construct a balanced sample of 4 years around 0.

Figure 2 provides a visual representation of our IV approach, after taking out municipality and cohort effects. For each municipality, time zero represents the first birth cohort affected by the compulsory schooling law reform. The y-axis on the right (left) side of the graph shows the change in compulsory schooling law from time -1 to time 0 is associated with a substantial increase in educational attainment (lifetime earnings). The graph suggests a sizable IV estimate on lifetime earnings of the reform-induced increase in schooling 10

In Section 3.3, we challenge the validity of the instrument by probing the stability of the IV estimates to alternative specifications, finding little cause for worry.

Alternative strategies The IV model identifies the education premiums among persons obliged to stay in school longer because of compulsory school laws. Because

\footnotetext{
${ }^{10}$ Estimation results from equation (7) show a strong first stage with an estimated coefficient on the instrument of 0.213 . This means that exposure to the compulsory schooling reform increased years of schooling by about one-fifth of a year. The F-statistic for the instrument is around 93, implying that weak instrument bias is not a concern for our analysis.
} 
of the local nature of these estimates, we will also apply two alternative identification strategies that are currently in use in the literature. ${ }^{11}$

Rather than using an instrument, our second strategy attempts to control directly for differences in ability when estimating equation (6). To this end, we use information on ability test scores from Norwegian military records. In Norway, military service is compulsory for all able males. Before entering the service, their medical and psychological suitability is assessed; this occurs for the great majority around their 18th birthday. The ability test scores are only available for cohorts born in 1950 or later. Our ability sample therefore consists of 325,233 individuals who were born during the period 1950-1963. This amounts to about $81.3 \%$ of the full sample.

The ability measure is a composite score from three speeded tests - arithmetics, word similarities, and figures ${ }^{12}$ The composite test score is an unweighted mean of the three scores. The score is reported in stanine (Standard Nine) units, a method of standardizing raw scores into a nine-point standard scale with a normal distribution, a mean of 5 , and a standard deviation of 2 . We add a full set of test score indicators to equation $(6)$.

Our final strategy is to use within-twin-pair estimation of equation (6). This strategy identifies the education premiums by comparing the difference in schooling of the twins in a pair with the difference in their earnings (see e.g. Griliches, 1979. Ashenfelter and Krueger, 1994). The idea is that twins share genetics and the same family background environment, possibly reducing the extent of selection bias. ${ }^{13}$

Our twins sample consists of 6,490 individuals, which is about $1.1 \%$ of the full sample. Unfortunately, our data do not allow us to distinguish between monozygotic and dizygotic twins. This means that our within-twin-pair estimates might be confounded by unobserved heterogeneity in genetics. As we only consider male twin pairs, we know from Weinberg's rule that about half of the males in the twins sample are monozygotic.

\footnotetext{
${ }^{11}$ Carneiro et al. (2011) show substantial population heterogeneity in the impact to college, raising concerns about the external validity of IV estimates of returns to schooling.

${ }^{12}$ The arithmetic test mirrors the test in the Wechsler Adult Intelligence Scale (WAIS); the word test is similar to the vocabulary test in WAIS; and the figures test is comparable to the Raven Progressive Matrix test. See Sundet et al. (2004, 2005) and Thrane (1977) for details.

${ }^{13}$ Although much used, within-twin-pair estimation has been criticized. First, there could be other differences between the twins that are unobservable to the researcher and that affect both the schooling decision and earnings. Second, within-pair estimates are likely to suffer from greater attenuation bias (see e.g. Bound and Solon, 1999; Isacsson, 2004). We reduce the problem of measurement error by using administrative data on earnings and education attainment rather than self-reported surveys.
} 


\subsection{Descriptive statistics}

Before turning to the estimation of the education premiums, we describe a few important features of our data.

We study the 1943-1963 cohorts during the period 1967-2010. This selection of cohorts provides up to 44 consecutive observations of individual earnings. However, our baseline model estimates age-specific education premiums from age 17 to 62 - a total of 46 years. As a result, our baseline estimates are based on an unbalanced panel of earnings. For the cohort born in 1949, we observe earnings between the ages of 18 and 62. For the cohorts born earlier (1943-1948), we miss one or more earnings observation between the ages of 17 and 23. For the cohorts born later (1953-1963), earnings are no longer observed at some point over the ages 48-62.
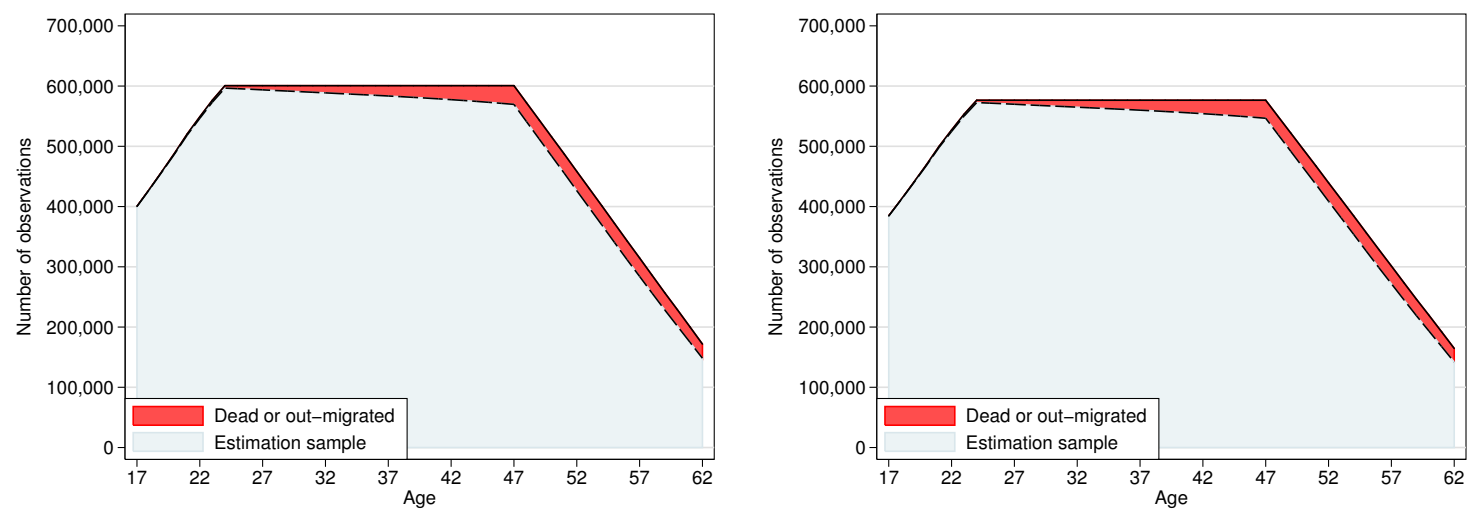

(a) Full sample

(b) IV sample
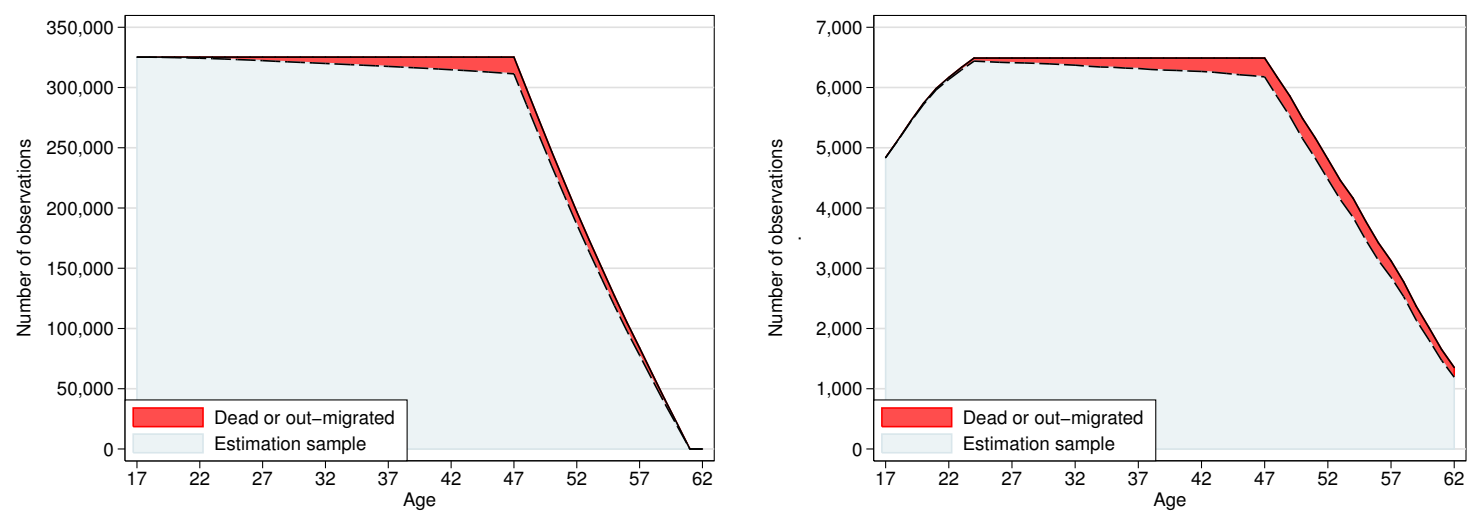

(c) IQ sample

(d) Twins sample

Figure 3. The size of each estimation sample over ages 17-62

Note: The IQ sample consists of individuals born during the period 1950-1963, while the other samples consist of cohorts born between 1943 and 1963. The graphs show the total number of observations over the ages 17-62, the attrition due to death and out-migration, and the size of each estimation sample.

Figure 3 shows the size of each sample by age. Over most of the working 
lifespan, these samples change little. However, the number of observations decrease significantly late (early) in the working lifespan because we are not observing the earnings of younger (older) cohorts at these ages. It is therefore reassuring to find that both the earnings profiles (cf. Figure 1) and the education premiums (cf. Figure 4 display smooth shapes over the life cycle. Nevertheless, we provide a sensitivity analysis in Section 3.3 , showing that our results are robust to restricting the sample to ages at which we have a balanced panel. Figure 3 also highlight that there is little attrition to the samples due to death and out-migration. As a result, our estimates barely move depending on the assumptions we make about the missing earnings of these individuals (see Section 3.3.

Table 1 reports summary statistics for key variables in our analysis. In Panel A, we present means and standard deviations for earnings or pension income over ages 17-24, 25- 44, 45-62, and 63-85. Panel B reports means and standard deviations for years of schooling. The increase in mean earnings over the life cycle is accompanied by an increase in the variance of earnings, in line with the fanning out of the earnings profiles by education levels.

Table 1. Summary statistics

\begin{tabular}{|c|c|c|c|c|}
\hline & Full sample & IV sample & IQ sample & Twins sample \\
\hline & $(1)$ & $(2)$ & $(3)$ & $(4)$ \\
\hline \multicolumn{5}{|c|}{ PANEL A. EARNINGS AND PENSION INCOME } \\
\hline \multirow[t]{2}{*}{ Mean earnings, age $17-24$} & 112367.4 & 112608.7 & 112888.7 & 112290.8 \\
\hline & $\left(\begin{array}{lll}67 & 120.0\end{array}\right)$ & $(67177.5)$ & $(60334.5)$ & $(63910.3))$ \\
\hline \multirow[t]{2}{*}{ Mean earnings, age $25-44$} & 295749.6 & 296493.3 & 320435.0 & 292040.0 \\
\hline & $(156622.4)$ & $(157591.9)$ & $(173176.8)$ & $(132507.2)$ \\
\hline \multirow[t]{2}{*}{ Mean earnings, age $45-62$} & 402068.9 & 402853.4 & 456179.9 & 399774.8 \\
\hline & $(329919.9)$ & $(332217.6)$ & $(332212.4)$ & $(297671.5)$ \\
\hline \multirow[t]{2}{*}{ Mean pensions, age $63-85$} & 274430.7 & 275021.8 & 297149.3 & 276606.6 \\
\hline & $(93427.6)$ & $(93470.1)$ & $(89887.3)$ & $(91483.9)$ \\
\hline \multicolumn{5}{|c|}{ PANEL B. EDUCATIONAL ATtainment } \\
\hline \multirow[t]{2}{*}{ Years of schooling } & 11.68 & 11.68 & 12.03 & 11.50 \\
\hline & $(2.83)$ & $(2.83)$ & $(2.61)$ & $(2.74)$ \\
\hline Number of observations & 600,679 & 576,512 & 325,231 & 6,490 \\
\hline
\end{tabular}

Note: For each sample, panel A displays average annual earnings and pension income over different age intervals, whereas panel B reports average years of schooling. Standard deviations are reported in parentheses. 


\section{Education premiums and rates of return}

\subsection{The earnings-schooling relationship}

Figure 4 displays OLS estimates of the education premium in earnings at every age. The estimated effects of schooling increase over most of the life cycle. The estimates start out negative when these men are young, reflecting that some individuals taking higher education are still in school, and that low-educated workers have considerably more work experience early in their careers. The education premiums rise quickly until individuals are in their late 40s. Equipped with education premiums at each age, we compute the corresponding IRR from equation (4). The first column of panel A in Table 2 reports the OLS estimate of IRR in earnings with standard errors computed from non-parametric bootstrap 14 This estimate suggests that a discount rate of 14 percent is necessary to equate the present value of earnings streams across schooling levels.

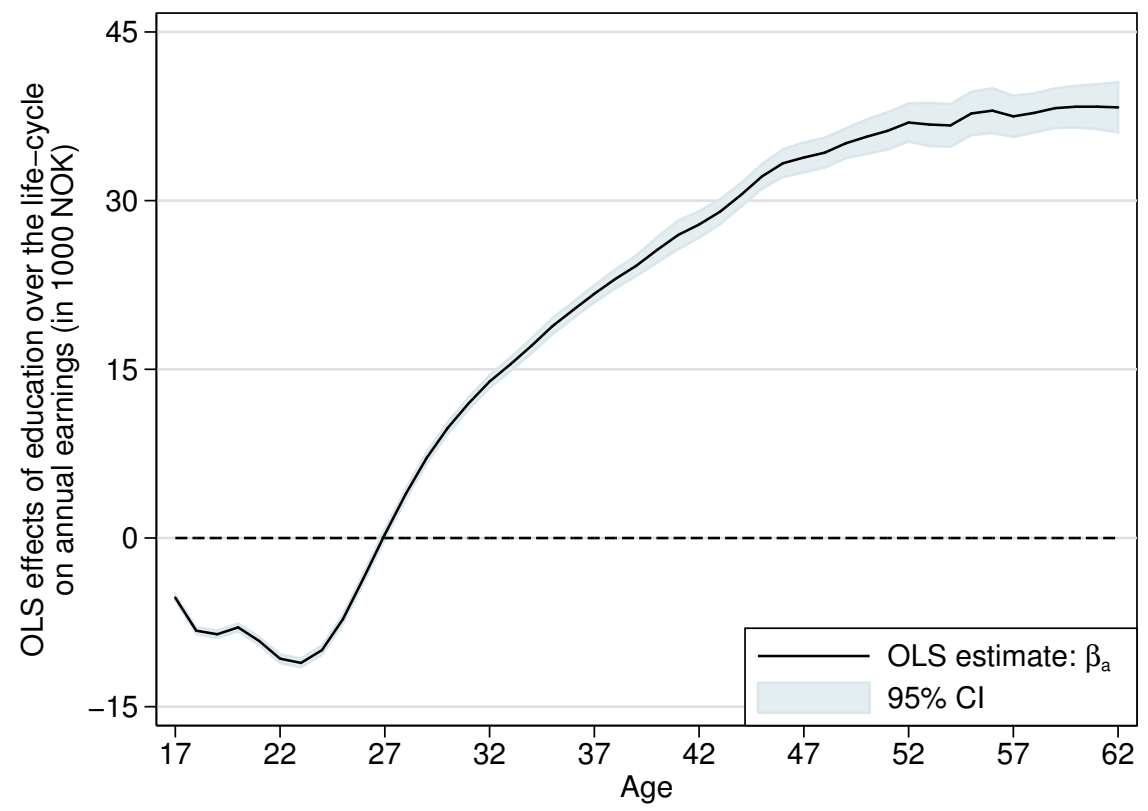

Figure 4. OLS estimates of age-specific education premiums

Note: This figure graphs OLS estimates of the age-specific education premiums for the full sample. All regressions include fixed effects for childhood municipality and birth cohort. Standard errors are heteroskedasticity robust and clustered at the municipality level. The $95 \%$ confidence intervals are drawn in shaded areas.

The other columns of panel A show IRR estimates when addressing the concern for selection bias. In every case, we compute the IRR from a full set of age-specific

\footnotetext{
${ }^{14}$ We use 250 bootstrap replications. Throughout the paper, in each iteration of the bootstrap we re-estimate the education premiums so that the standard errors account for the fact that $\hat{\beta}_{a}$ is itself an estimated object.
} 
education premiums. Panel B summarizes how these education premiums vary across the life cycle by estimating the effect of schooling on average earnings over different age intervals. Panel $\mathrm{C}$ displays the education premium in lifetime earnings. This panel also reports the impact of schooling on the annuity value of the sum of earnings, discounted by the market interest rates. All estimates in panels B and C are reported in Norwegian Kroner (NOK), while the estimated effects relative to the dependent means are reported in squared brackets.

Table 2. Education premiums and internal rates of return

\begin{tabular}{|c|c|c|c|c|}
\hline & Full sample & IV sample & IQ sample & Twins sample \\
\hline & $(1)$ & $(2)$ & $(3)$ & $(4)$ \\
\hline & OLS & IV & IQ control & Twin FE \\
\hline \multicolumn{5}{|c|}{$\underline{\text { PANEL A. INTERNAL RATE OF RETURN }}$} \\
\hline Internal rate of return & $\begin{array}{l}0.140^{* * *} \\
(0.001)\end{array}$ & $\begin{array}{l}0.105^{* *} \\
(0.048)\end{array}$ & $\begin{array}{l}0.122^{* * *} \\
(0.001)\end{array}$ & $\begin{array}{c}0.117^{* * *} \\
(0.011)\end{array}$ \\
\hline \multicolumn{5}{|c|}{ PANEL B. EduCATION PREMIUMS OVER THE LIFE-CyCle } \\
\hline Mean earnings, ages $17-24$ & $\begin{array}{c}-9073.5^{* * *} \\
(270.8) \\
{[-0.081]}\end{array}$ & $\begin{array}{c}-5097.8^{* * *} \\
(1826.4) \\
{[-0.045]}\end{array}$ & $\begin{array}{c}-8736.4^{* * *} \\
(165.4) \\
{[-0.077]}\end{array}$ & $\begin{array}{c}-6344.5^{* * *} \\
(405.1) \\
{[-0.056]}\end{array}$ \\
\hline Mean earnings, ages $25-44$ & $\begin{array}{c}15493.5^{* * *} \\
(288.1) \\
{[0.051]}\end{array}$ & $\begin{array}{c}5918.1^{*} \\
(3285.7) \\
{[0.021]}\end{array}$ & $\begin{array}{c}11571.2^{* * *} \\
(229.2) \\
{[0.036]}\end{array}$ & $\begin{array}{c}7583.5^{* * *} \\
(942.8) \\
{[0.026]}\end{array}$ \\
\hline Mean earnings, ages $45-62$ & $\begin{array}{c}38285.2^{* * *} \\
(987.2) \\
{[0.090]}\end{array}$ & $\begin{array}{c}10186.4 \\
(6967.1) \\
{[0.025]}\end{array}$ & $\begin{array}{c}32409.4^{* * *} \\
(937.9) \\
{[0.068]}\end{array}$ & $\begin{array}{c}23745.1^{* * *} \\
(2329.1) \\
{[0.056]}\end{array}$ \\
\hline \multicolumn{5}{|c|}{$\underline{\text { PANEL C. LifETIME EDUCATION PREMIUMS }}$} \\
\hline Mean lifetime earnings & $\begin{array}{c}18636.1^{* * *} \\
(416.4) \\
{[0.063]}\end{array}$ & $\begin{array}{c}7114.1^{* *} \\
(3382.5) \\
{[0.024]}\end{array}$ & $\begin{array}{c}12936.2^{* * *} \\
(333.5) \\
{[0.042]}\end{array}$ & $\begin{array}{c}10534.5^{* * *} \\
(1023.1) \\
{[0.036]}\end{array}$ \\
\hline Annuity lifetime earnings & $\begin{array}{c}9266.1^{* * *} \\
(195.3) \\
{[0.052]} \\
\end{array}$ & $\begin{array}{c}4123.2^{* *} \\
(1881.1) \\
{[0.024]}\end{array}$ & $\begin{array}{c}6143.3^{* * *} \\
(156.9) \\
{[0.032]} \\
\end{array}$ & $\begin{array}{c}5014.5^{* * *} \\
(565.9) \\
{[0.029]} \\
\end{array}$ \\
\hline$N$ & 600,679 & 325,231 & 6,490 & 576,512 \\
\hline
\end{tabular}

Note: For each identification strategy, we report estimates of IRR (Panel A), education premiums in average earnings over different age intervals (Panel B), and education premiums in mean lifetime earnings and annuity lifetime earnings (Panel C). All regressions include fixed effects for childhood municipality and birth cohort. Standard errors of the education premiums are heteroskedasticity robust and clustered at the municipality level. The standard errors of the IRR are computed by non-parametric bootstrap with 250 replications. All earnings estimates are reported in Norwegian Kroner (NOK), while the estimated effect relative to the dependent mean is reported in squared brackets.

${ }^{*} \mathrm{p}<0.10,{ }^{* *}<0.05,{ }^{* * *} \mathrm{p}<0.01$. 
There are clear patterns in our results, independent of identification strategy. Additional schooling gives higher lifetime earnings and steeper age-earnings profiles. Taken together, the age-specific education premiums give IRR estimates which are substantially higher than the market interest rates typically observed. This finding is mirrored in the positive and significant effects of schooling on the annuity lifetime earnings. However, the estimated education premiums in lifetime earnings tend to be even higher because most of the earnings gains to schooling arise late in the working life and are discounted heavily in the annuity calculations. For example, the OLS estimates imply that an additional year of schooling increases lifetime earnings by 6.3 percent (NOK 18,631) while annuity lifetime earnings increases by 5.2 percent (NOK 9,266).

There are, however, some noticeable differences in the results across the identification strategies. These differences are unlikely to be due to the discrepancies in sample selection, as the OLS estimates are very similar across the samples ${ }^{15}$ In particular, addressing the concern for selection bias decreases the OLS estimates of both the education premiums and the IRR. A common interpretation of this finding is that individuals with greater earnings capacity have chosen to acquire more schooling.

\subsection{Accounting for taxes and pension entitlements}

Like most studies of the returns to schooling, the estimates in Table 2 are based on pre-tax earnings. Since tuition costs are negligible in Norway, proportional taxes on earnings would have no effect on estimated IRR as they reduce earnings by the same proportion regardless of educational choices (Heckman et al., 1998, 2008). For the same reason, ignoring earnings-related pension entitlement would not affect the IRR estimates if pension income was proportional to lifetime earnings. However, the progressive nature of the Norwegian tax and pension system may attenuate the incentives to invest in education.

In the first and second row of Table 3, we report IRR estimates based on pre-tax earnings and after-tax income, respectively. As in most OECD countries, the tax system in Norway is progressive through deductions and surtaxes ${ }^{16}$ Comparing the estimates, we find that accounting for income taxation reduces the IRR estimates by around 10-15 percent. To understand how taxes affect the incentives to invest in education, Figure 5 presents OLS estimates of the education premium in after-tax income over the life cycle in Figure 5. We can see that progressive taxes not only

\footnotetext{
${ }^{15}$ The results are available from the authors upon request.

${ }^{16}$ Appendix, Section A.2, describes the tax system in more detail and presents marginal and average tax rates on labor income in different years.
} 
reduces the education premium in lifetime income but also attenuate the slope of the age-specific education premiums.

Table 3. IRR estimates accounting for taxes and pension income

\begin{tabular}{|c|c|c|c|c|}
\hline & Full sample & IV sample & IQ sample & Twins sample \\
\hline & $(1)$ & $(2)$ & $(3)$ & $(4)$ \\
\hline & OLS & IV & IQ control & Twin FE \\
\hline Pre-tax earnings & $\begin{array}{c}0.140^{* * *} \\
(0.001)\end{array}$ & $\begin{array}{l}0.105^{* *} \\
(0.048)\end{array}$ & $\begin{array}{c}0.122^{* * *} \\
(0.001)\end{array}$ & $\begin{array}{c}0.117^{* * *} \\
(0.011)\end{array}$ \\
\hline After-tax income & $\begin{array}{c}0.118^{* * *} \\
(0.001)\end{array}$ & $\begin{array}{l}0.094^{* *} \\
(0.045)\end{array}$ & $\begin{array}{c}0.109^{* * *} \\
(0.001)\end{array}$ & $\begin{array}{c}0.106^{* * *} \\
(0.010)\end{array}$ \\
\hline $\begin{array}{l}\text { After-tax income } \\
\quad+\text { pension income }\end{array}$ & $\begin{array}{c}0.119^{* * *} \\
(0.001)\end{array}$ & $\begin{array}{l}0.095^{* *} \\
(0.045)\end{array}$ & $\begin{array}{c}0.110^{* * *} \\
(0.001)\end{array}$ & $\begin{array}{c}0.107^{* * *} \\
(0.010)\end{array}$ \\
\hline$N$ & 600,679 & 576,512 & 325,231 & 6,490 \\
\hline
\end{tabular}

Note: For each identification strategy, we report estimates of IRR in pre-tax earnings, after-tax income, and aftertax income + pension entitlements. All regressions include fixed effects for childhood municipality and birth cohort. The standard errors are computed by non-parametric bootstrap with 250 replications.

${ }^{*} \mathrm{p}<0.10,{ }^{* *}<0.05, * * * \mathrm{p}<0.01$

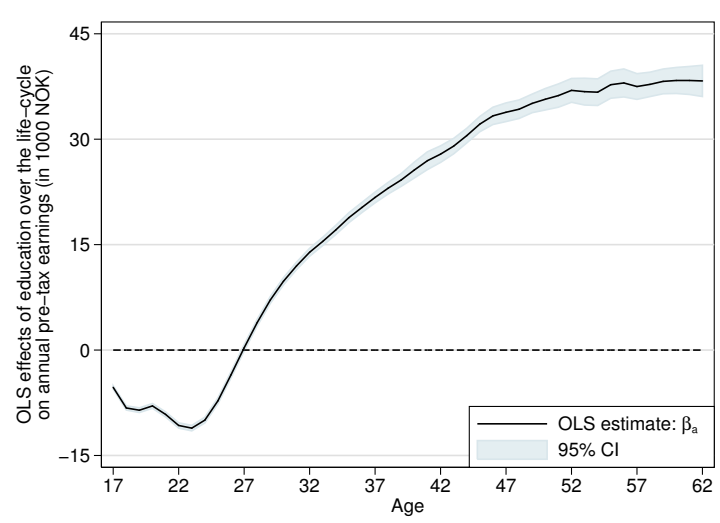

(a) Pre-tax earnings

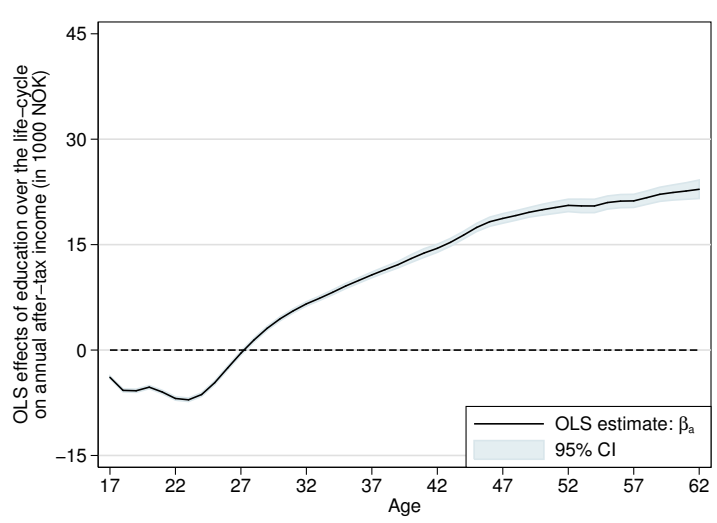

(b) After-tax income

Figure 5. OLS estimates of education premiums in pre-tax earnings and after-tax income

Note: This figure graphs OLS estimates of the age-specific education premiums in pre-tax earnings and after-tax income for the full sample. All regressions include fixed effects for childhood municipality and birth cohort. Standard errors are heteroskedasticity robust and clustered at the municipality level. Shaded areas show $95 \%$ CIs.

In the third row of Table 3 , we report IRR estimates based on a measure of aftertax income that includes future earnings-related pension entitlements. We calculate after-tax pension entitlements based on individuals' earnings histories, assuming that each individual retires after age 62 and dies at age 85; these assumptions match the 
typical retirement age and life expectancy of the cohorts born between 1943 and 1963 (Brunborg et al., 2008). We find that the IRR estimates barely move when we account for pensions, irrespective of the identification strategy we employ. This is largely because pension income is received at older ages. As a result, it is discounted heavily in the computation of the IRR. This suggests that earnings-related pension entitlements play a minor role for the incentives to invest in education.

\subsection{Sensitivity analysis}

IV strategy An important requirement for our IV approach to be valid is that the timing of the reform implementation is unrelated to different underlying cohort trends in earnings across municipalities. We begin by investigating the relationship between the timing of the reform and baseline municipality characteristics. To this end, we estimate the following equation

$$
T_{m t}=\left(\Gamma_{t} \times B_{m, 1960}\right)^{\prime} \psi_{t}+\tau_{m}+\tau_{t}+\chi_{m t}
$$

where $T_{m t}$ is an indicator variable that is equal to 1 if municipality $m$ implemented the reform by year $t$ (and 0 otherwise), and $B_{m, 1960}$ is a vector with municipalitylevel information from year 1960 on demographic, socio-economic and political characteristics. By interacting these variables with a vector of time-dummies $\Gamma_{t}$, we can estimate whether the timing of the reform is correlated with observed municipality characteristics. Appendix Figure A.2 plots the estimated coefficients from the vector of coefficients $\psi_{t}$ for each year $t$ (and the associated $95 \%$ confidence intervals). We find no evidence of a systematic relationship between the timing of the reform implementation and baseline municipality characteristics.

To further increase the confidence in our IV estimates, we consider two ways to allow for differential cohort trends across municipalities. First, we estimate municipality-specific cohort trends over the pre-reform period based on birth cohorts born 1930-1960. For each municipality, we obtain estimates of linear and quadratic cohort trends in earnings and years of schooling. We then add controls for these cohort trends in both the first and second stage of the IV model. Columns 2 and 3 of Table 4 show that the IRR estimates remain sizable after controlling for pre-reform cohort trends. Second, we include interactions between each municipality-level characteristic and linear or quadratic cohort trends. In doing so, we allow the reform implementation to be related to different underlying cohort trends across municipalities, depending on their pre-reform characteristics. Columns (4) and (5) of Table 4 support the conclusion that it was financially profitable to take additional 
schooling because the IRR is substantially higher than the market interest rates.

Table 4. Robustness of IV estimates

\begin{tabular}{|c|c|c|c|c|c|}
\hline & \multirow{3}{*}{$\frac{\text { Baseline }}{(1)}$} & \multicolumn{2}{|c|}{ Pre-reform trend } & \multicolumn{2}{|c|}{ Interacted trend } \\
\hline & & (2) & (3) & (4) & (5) \\
\hline & & Linear & Quadratic & Linear & Quadratic \\
\hline \multicolumn{6}{|c|}{ Panel A. IV estimates } \\
\hline \multirow[t]{2}{*}{ Internal rate of return } & $0.105^{* *}$ & $0.099^{* *}$ & $0.080^{*}$ & $0.074^{*}$ & $0.116^{* * *}$ \\
\hline & $(0.048)$ & $(0.046)$ & $(0.044)$ & $(0.044)$ & $(0.043)$ \\
\hline \multicolumn{6}{|c|}{ Panel B. First stage estimates } \\
\hline \multirow[t]{2}{*}{ Coefficient } & $0.213^{* * *}$ & $0.215^{* * *}$ & $0.216^{* * *}$ & $0.214^{* * *}$ & $0.220^{* * *}$ \\
\hline & $(0.022)$ & $(0.020)$ & $(0.019)$ & $(0.018)$ & $(0.017)$ \\
\hline F-value (instrument) & 92.76 & 119.32 & 133.41 & 146.18 & 164.97 \\
\hline$N$ & 576,512 & 576,512 & 576,512 & 576,512 & 576,512 \\
\hline
\end{tabular}

Note: Column (1) repeats the baseline results, while columns (2) and (3) include controls for linear and quadratic cohort trends for each municipality and columns (4) and (5) also add interactions between linear and quadratic cohort trends and the baseline municipality characteristics (measured in 1960) that are listed in Figure A.2 All regressions include fixed effects for childhood municipality and birth cohort. The standard errors of the IRRs (Panel A) are computed by non-parametric bootstrap with 250 replications. Standard errors of the first-stage estimates (Panel B) are heteroskedasticity robust and clustered at the municipality level.

${ }^{*} \mathrm{p}<0.10,{ }^{* *}<0.05,{ }^{* * *} \mathrm{p}<0.01$.

Sensitivity to unbalanced panel So far, our analysis has been based on data for the 1943-1963 cohorts during the period 1967-2010. This selection of cohorts provides up to 44 consecutive observations of individual earnings. However, our baseline model estimates age-specific education premiums from age 17 to 62 - a total of 46 years. As a result, our baseline estimates are based on an unbalanced panel of earnings. It is therefore reassuring to find that both the earnings profiles (cf. Figure 1) and the education premiums (cf. Figure 4) display smooth shapes over the life cycle. Nevertheless, Table 5 provides a sensitivity analysis, showing that our results are robust to restricting the sample to ages at which we have a balanced panel. In particular, the second row presents IRR estimates based on complete records of earnings from age 17 to 50 for the cohorts 1950-1960. By comparing these estimates to those reported in the first row, it is clear that our findings are robust to restricting the IRR calculation to education premiums over ages 17-50.

In Table 5, we also show that our IRR estimates change little depending on the assumptions we make about the missing earnings of individuals who die or migrate. In the third row, we keep these individuals in our estimation sample by assigning zero earnings to ages at which their earnings observations are missing. In the fourth 
column, we replace the missing earnings observations with an individual's average earnings over the past five years prior to death or migration. In either case, the IRR estimates are quite similar to the baseline results.

Table 5. Sensitivity of IRR estimates to an unbalanced panel

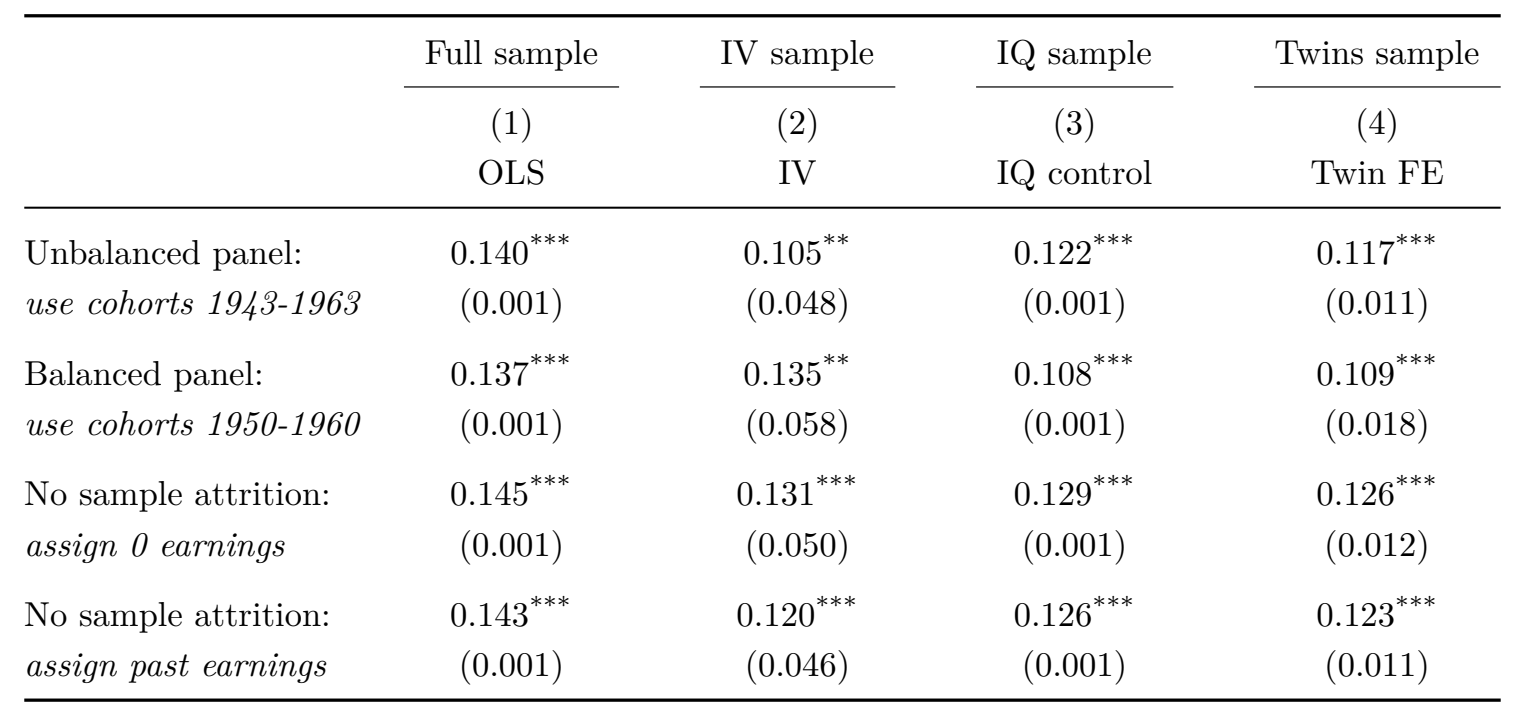

Note: The first row repeats the baseline results; the second row restricts the IRR calculation to education premiums over the ages 17-50 for the cohorts 1950-1960; the third row keep individuals who die or migrate in our estimation sample by assigning zero earnings to ages at which their earnings observations are missing; the fourth column replaces the missing earnings observations with an individual's average earnings over the past five years prior to death or migration. All regressions include fixed effects for childhood municipality and birth cohort. The standard errors are computed by non-parametric bootstrap with 250 replications.

$* \mathrm{p}<0.10, * *<0.05, * * * \mathrm{p}<0.01$.

\section{Comparison with Mincer regressions}

Mincer regressions are widely used to estimate the IRR. As discussed in Heckman et al. (2006), this approach recovers the IRR only under a number of strong assumptions. Our exceptionally rich data allows us to relax some of these assumptions and to assess the extent to which they create bias in Mincer regressions.

We begin by using cross-section data to estimate the Mincer regression given in equation (1). Figure 6 reports OLS estimates of the coefficient on years of schooling for each cross-section over the period 1980-2010. These estimates are considerably lower than the IRR we obtained from our estimates of education premiums at every age. This holds true both when we consider all males aged 16-72 in a given year and when we restrict the estimation sample to include the same set of cohorts in the two analyses (i.e. the 1943-1963 cohorts). The increasing pattern over time points to a non-stationarity environment, either due to cohort or calender time effects.

In Table 6, we explore the relative importance of several key assumptions behind the Mincer regression. For brevity, we focus on year 2005. The first row of Panel 
A considers males aged 16-72. Independent of identification strategy, the results suggest a significant downward bias in the IRR estimates from the Mincer model. ${ }^{17}$ In the second row of Panel A, we restrict the sample to the 1943-1963 cohorts. While the IRR estimates increase significantly, they remain substantially lower than our baseline results.

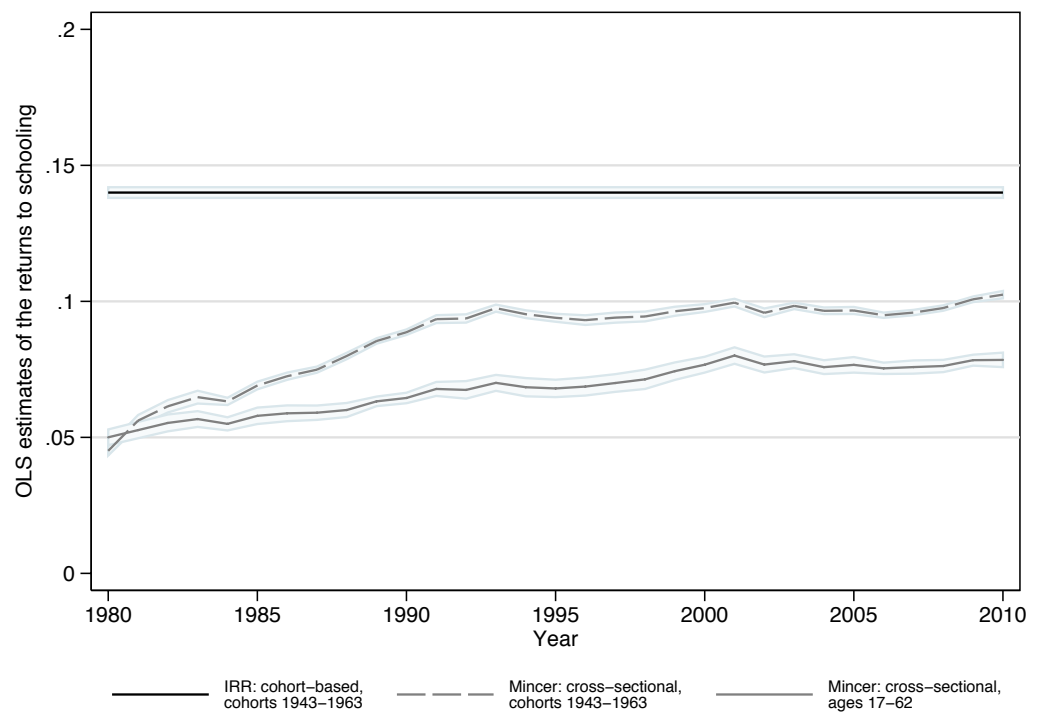

Figure 6. Comparison of OLS estimates of returns to schooling

Note: The horizontal line displays our baseline OLS estimate of IRR in pre-tax earnings, which is computed from age-specific education premiums over the life-cycle of the 1943-1963 cohorts. The Mincer regressions use crosssection data on males with non-zero earnings. In each cross-section over the period 1980-2010, we regress log pre-tax earnings on years of schooling, experience and experience squared. The solid line represents estimates for individuals aged 16-72 in a given year, whereas the stippled line represents estimates for which the sample is restricted to the 1943-1963 cohorts. Shaded areas show 95\% confidence intervals.

A possible explanation for the downward bias in the IRR estimates is that the Mincer model assumes a stationary environment. This assumption allows researchers to use cross-section experience-earnings profiles as guides to the life cycle earnings of persons. However, recent evidence suggests that wage patterns have changed substantially over time or across cohorts (see e.g. MaCurdy and Mroz, 1995, Card and Lemieux, 2001), raising doubts about the stationarity assumption. The third row of Panel A pools the cross-sectional data sets over the period 1980-2010. This allows us to include a full set of indicator variables for calender time effects, absorbing aggregate changes in skill prices over time. By doing so, the estimates from the Mincer are significantly reduced, creating an even larger discrapency to our baseline IRR estimates.

\footnotetext{
${ }^{17}$ Table 6 does not report IV estimates because the compulsory schooling instrument does not allow us to identify the coefficient on years of schooling in the Mincer regression.
} 
Table 6. Comparison of returns to schooling estimates

\begin{tabular}{|c|c|c|c|}
\hline & OLS & IQ control & Twin FE \\
\hline & $(1)$ & $(2)$ & $(3)$ \\
\hline \multicolumn{4}{|c|}{ PANEL A. INTERNAL RATE OF RETURN BASED ON MINCER REGRESSIONS } \\
\hline Cross section data, 2005: & $0.077^{* * *}$ & $0.072^{* * *}$ & $0.052^{* * *}$ \\
\hline Individuals aged $17-62$ & $(0.001)$ & $(0.002)$ & $(0.005)$ \\
\hline$N$ & $1,208,601$ & 902,933 & 21,420 \\
\hline Cross section data, 2005: & $0.097^{* * *}$ & $0.083^{* * *}$ & $0.071^{* * *}$ \\
\hline Cohorts born 1943-1963 & $(0.001)$ & $(0.001)$ & $(0.007)$ \\
\hline$N$ & 550,089 & 306,720 & 6,026 \\
\hline Pooled cross-sections, 1980-2010: & $0.072^{* * *}$ & $0.068^{* * *}$ & $0.054^{* * *}$ \\
\hline Cohorts born 1943-1963 & $(0.001)$ & $(0.001)$ & $(0.002)$ \\
\hline$N$ & 550,089 & 306,720 & 6,026 \\
\hline
\end{tabular}

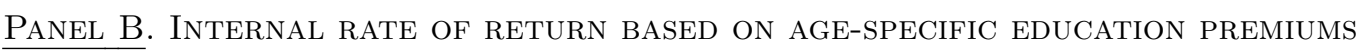

$\begin{array}{lccc}\text { Baseline estimate: } & 0.140^{* * *} & 0.122^{* * *} & 0.117^{* * *} \\ \text { Cohorts born 1943-1963 } & (0.001) & (0.001) & (0.011) \\ N & 600,679 & 325,231 & 6,490 \\ \text { Assign zero earnings while in school: } & 0.107^{* * *} & 0.083^{* * *} & 0.074^{* * *} \\ \text { Cohorts born 1943-1963 } & (0.001) & (0.001) & (0.007) \\ N & 600,679 & 325,231 & 6,490 \\ \text { Drop obs. with zero earnings in 2005: } & 0.116^{* * *} & 0.107^{* * *} & 0.084^{* * *} \\ \text { Cohorts born 1943-1963 } & (0.001) & (0.001) & (0.013) \\ N & 550,089 & 306,720 & 6,026\end{array}$

Note: Panel A reports estimates from Mincer regressions using data on males with non-zero earnings. In each row, we regress log pre-tax earnings on years of schooling, experience and experience squared. We report estimates for the schooling coefficient. The first row uses data for individuals aged 16-72 in 2005, while the second row restricts this sample to the 1943-1963 cohorts. The third row pools cross-section data over the period 1980-2010 for the 1943-1963 cohorts. Panel B reports estimates of IRR in pre-tax earnings, which is computed from age-specific education premiums over the life-cycle of males from the 1943-1963 cohorts. The first row reports our baseline estimates, the second row assigns zero earnings to individuals while in school, and the third row drops observations with zero earnings in 2005. All regressions include fixed effects for childhood municipality. Standard errors in Panel A are heteroskedasticity robust and clustered at the municipality level. Standard errors in Panel B are computed by non-parametric bootstrap with 250 replications.

${ }^{*} \mathrm{p}<0.10,{ }^{* *}<0.05, * * * \mathrm{p}<0.01$.

In Panel B of Table 6, we explore two alternative explanations. We first examine the importance of Mincer's assumption of no earnings while in school. In the absence of tuition, this assumption implies that the costs of an additional year of schooling is equal to an individual's total earnings capacity. However, many high school and college students actually have non-zero earnings while in school (NCES, 2013 , Kalenkoski and Pabilonia, 2012), which should generate a downward bias in the estimates from the Mincer regression. In the second row of Panel B, we assign zero earnings to individuals while they are in school and re-estimate the education premiums at every age. Equipped with the new education premiums at each age, we 
compute the corresponding IRR from equation (4). We find that earnings while in school account for much of the discrapency between our baseline IRR estimates and those produced by the Mincer regression. This finding is consistent with the fact that earnings accumulated early in life receive a lot of weight in the IRR calculations.

The other explanation we explore is that education affects employment and therefore creates an endogenous sample selection in the Mincer regressions of log earnings on schooling and experience. This would create downward bias in the estimated rates of return from the Mincer model, insofar additional schooling increases the employment rate of individuals with low potential earnings. In the third row of Panel B, we drop individuals with zero earnings in 2005 and re-estimate the education premiums at every age. Equipped with the new education premiums at each age, we compute the corresponding IRR from equation (4). Our results suggest the assumption of exogenous employment leads to significant downward bias in the IRR estimates.

\section{Conclusion}

The objective of this paper was to provide a detailed picture of the causal relationship between schooling and earnings over the life cycle, following individuals across their working lifespan. We addressed a number of key questions: What do the education premiums look like over the life cycle? What is the impact of schooling on lifetime earnings? How does the IRR compare with the market interest rates typically observed? To what extent does progressive taxes attenuate the rates of return to schooling? To investigate these important questions, we exploited a unique source of population panel data containing records for every Norwegian male from 1967 to 2010. To account for endogeneity of schooling, we applied three identification strategies that are currently in use in the literature: (i) compulsory schooling reform as an instrument for schooling, (ii) controls for ability test scores, and (iii) within-twin-pair estimation. The analysis was explicitly ex post and focused on identifying the actual returns earned by certain cohorts over their life cycle.

We started our analysis by estimating education premiums at each age. The findings revealed that additional schooling gives higher lifetime earnings and steeper age-earnings profile, in line with predictions from human capital theory. The agespecific education premiums implied an IRR of around 10 percent, after taking into account income taxes, earnings-related pension entitlements and tuition costs. Under standard conditions, this finding suggests it was financially profitable to take additional schooling because the rate of return is substantially higher than the market 
interest rates typically observed.

Our analysis relaxed many of the strong assumptions that are typical in the literature. ${ }^{18}$ Importantly, we estimated education premiums experienced by individuals over their life cycle and the corresponding rates of return, without assuming multiplicative separability between schooling and experience or a stationary environment. Our approach also relaxed Mincer's assumption of no earnings while in school and exogenous post-schooling employment. Unlike most of the literature, our estimated rates of return accounted for income taxation and earnings-related pension entitlements.

In the empirical analysis, we expored how the returns to schooling are affected by incorporating these income components and we compare our estimates of IRR to those produced by Mincer regressions. We found that accounting for income taxation reduces the IRR estimates by around 10-15 percent, whereas earnings-related pention entitlements play a minor role for the incentives to invest in education. Our estimates also revealed that Mincer regressions understate substantially the rates of return. When we explored the reasons for this downward bias, our results point to Mincer's assumptions of no earnings while in school and exogenous post-schooling employment.

\section{References}

Aaberge, R., Mogstad, M., and Peragine, V. (2011). Measuring long-term inequality of opportunity. Journal of Public Economics, 95:193-204.

Aakvik, A., Salvanes, K. G., and Vaage, K. (2010). Measuring heterogeneity in the returns to education using an education reform. European Economic Review, 54:483-500.

AID (2009). Om lov om endringer $i$ folketrygdloven (ny alderspensjon). Det Kongelige Arbeids- og Inkluderingsdepartementet, Ot. prp. nr. 37 (2008-2009), Oslo (in Norwegian).

Angrist, J. D. and Krueger, A. B. (1991). Does compulsory school attendance affect schooling and earnings? Quarterly Review of Economics, 106(4):979-1014.

Ashenfelter, O. and Krueger, A. (1994). Estimates of the economic return to schooling from a new sample of twins. American Economic Review, 84:1157-1173.

\footnotetext{
${ }^{18}$ Heckman et al. (2006 2008) examine the role of taxes, tuition and a flexible relationship between earnings, schooling, and experience in the estimation of IRR. However, these studies assume that schooling is exogenous and also require a method for extrapolating the earnings function to work experience levels not observed in the data.
} 
Black, S. E., Devereux, P. J., and Salvanes, K. G. (2005). Why the apple doesn't fall far: Understanding intergenerational transmission of human capital. American Economic Review, 95:437-449.

Bound, J. and Solon, G. (1999). Double trouble: On the value of twins-based estimation of the returns to schooling. Economics of Education Review, 18:169182.

Brunborg, H., Fredriksen, D., Stølen, N. M., and Texmon, I. (2008). Utviklingen $i$ levealder og utforming av delingstall $i$ et reformert pensjonssystem. Statistisk sentralbyrå, Rapporter 2008/23, Oslo (in Norwegian).

Card, D. (1999). The causal effect of education on earnings. Handbook of Labor Economics, 3(1):1801-1863.

Card, D. and Lemieux, T. (2001). Can falling supply explain the rising return to college for younger men? a cohort-based analysis. Quarterly Journal of Economics, 116(2):705-746.

Carneiro, P., Hansen, K., and Heckman, J. (2003). Estimating distributions of treatment effects with an application to the returns to schooling and measurement of the effects of uncertainty on college choice. International Economic Review, $44(2): 361-422$.

Carneiro, P. and Heckman, J. (2002). The evidence on credit constraints in postsecondary schooling. Economic Journal, 112(482):705-734.

Carneiro, P., Heckman, J. J., and Vytlacil, E. J. (2011). Estimating marginal returns to education. American Economic Review, 101(6):2754-81.

Cunha, F. and Heckman, J. (2007). Identifying and estimating the distributions of ex post and ex ante returns to schooling. Labour Economics, 14(6):870-893.

Cunha, F., Heckman, J., and Navarro, S. (2005). Separating uncertainty from heterogeneity in life cycle earnings. Oxford Economic Papers, 57(2):191-261.

Devereux, P. and Fan, W. (2011). Earnings Returns to the British Education Expansion. Economics of Education Review, 30(6):1153-1166.

Devereux, P. and Hart, R. A. (2010). Forced to be rich? Returns to compulsory schooling in Britain. Economic Journal, 120(549):1345-1364. 
Dustmann, C. and Van Soest, A. (2007). Part-time work, school success and school leaving. Empirical Economics, 32(2):277-299.

Griliches, Z. (1979). Sibling models and data in economics: Beginning of a survey. Journal of Political Economy, 87(2):37-64.

Harmon, C., Oosterbeek, H., and Walker, I. (2003). The returns to education: Microeconomics. Journal of Economic Surveys, 17:115-155.

Harmon, C. and Walker, I. (1995). Estimating of the economic return to schooling for the united kingdom. American Ecnomic Review, 85:1278-1296.

Heckman, J., Lochner, L., and Taber, C. (1998). Tax policy and human-capital formation. American Economic Review, Papers and Proceedings of the Hundred and Tenth Annual Meeting of the American Economic Association, 88(2):293-297.

Heckman, J., Lochner, L., and Todd, P. (2006). Earnings functions, rates of return and treatment effects: The Mincer equation and beyond. Handbook of the Economics of Education, 1:307-458.

Heckman, J., Lochner, L., and Todd, P. (2008). Earnings functions and rates of return. Journal of Human Capital, 2:1-31.

Hernaes, E., Markussen, S., Piggott, J., and Vestad, O. (2013). Does retirement age impact mortality? Journal of Health Economics, 32(3):586-598.

Hotz, V. J., Xu, L. C., Tienda, M., and Ahituv, A. (2002). Are there returns to the wages of young men from working while in school? Review of Economics and Statistics, 84(2):221-236.

Isacsson, G. (2004). Estimating the economic return to educational levels using data on twins. Journal of Applied Econometrics, 19:99-119.

Kalenkoski, C. M. and Pabilonia, S. W. (2012). Time to work or time to play: The effect of student employment on homework, sleep, and screen time. Labour Economics, 19(2):211-21.

Lochner, L. J. and Monge-Naranjo, A. (2011). The nature of credit constraints and human capital. American Economic Review, 101(6):2487-2529.

Machin, S., Salvanes, K. G., and Pelkonen, P. (2012). Education and mobility. Journal of the European Economic Association, 10(2):417-450. 
MaCurdy, T. and Mroz, T. (1995). Measuring macroeconomic shifts in wages from cohort specifications. Unpublished Manuscript, Stanford University and University of North Carolina.

Meghir, C. and Palme, M. (2005). Educational reform, ability, and family background. American Economic Review, 95(1):414-424.

Mincer, J. (1974). Schooling, Earnings and Experience. Columbia University Press, New York.

Monstad, K., Propper, C., and Salvanes, K. G. (2008). Education and fertility: Evidence from a natural experiment. Scandinavian Journal of Economics, 110:827852.

NAV (2013). Om alderspensjon. Nav.no. URL: http://www.nav.no/Pensjon/Alderspensjon/Om+alderspensjon - Last accessed: 19/4/2013 (in Norwegian).

NCES (2013). The Condition of Education 2013. U.S. Department of Education, Institute of Education Statistics, National Center for Education Statistics 2013-037.

Oreopolous, P. (2006). Estimating average and local average treatment effects of education when compulsory schooling laws really matter. American Economic Review, 96:152-175.

Psacharopoulos, G. and Patrinos, H. A. (2004). Returns to investments in education: A further update. Education Economics, 12(2):111-134.

Skatteetaten (1991-2010). Lignings-ABC. Ar 1991-2010. Skattedirektoratet, Oslo (in Norwegian).

SSB (1975). Historisk oversikt over skattesatser m.v. Del I, årene til og med 1969. Statistisk sentralbyrå, Arbeidsnotat 75/5, Oslo (in Norwegian).

SSB (1988). Skatter og overføringer til private: Historisk oversikt over satser mv. årene 1970-1988, revidert utgave. Statistisk sentralbyrå, Rapporter 88/20, Oslo (in Norwegian).

SSB (1994). Skatter og overføringer til private: Historisk oversikt over satser mv. årene 1975-1994. Statistisk sentralbyrå, Rapporter 94/21, Oslo (in Norwegian).

Sundet, J. M., Barlaug, D. G., and Torjussen, T. M. (2004). The end of the flynn effect? a study of secular trends in mean intelligence test scores of Norwegian conscripts during half a century. Intelligence, 32:349-362. 
Sundet, J. M., Tambs, K., Harris, J. R., Magnus, P., and Torjussen, T. M. (2005). Resolving the genetic and environmental sources of the correlation between height and intelligence: A study of nearly 2600 Norwegian male twin pairs. Twin Research and Human Genetics, 7:1-5.

Thrane, V. C. (1977). Evneprøving av Utskrivingspliktige i Norge 1950-53. Arbeidsrapport nr. 26, INAS (in Norwegian). 


\section{A Appendix}

\section{A.1 Figures and tables}

Table A.1. Implementation of reform across cohorts 1943-1963

\begin{tabular}{|c|c|c|c|c|c|}
\hline \multirow[b]{2}{*}{ Cohort: } & \multirow[t]{2}{*}{ All } & \multicolumn{2}{|c|}{ Treated } & \multicolumn{2}{|c|}{ Non-treated } \\
\hline & & \multicolumn{2}{|c|}{ (\% of all) } & \multicolumn{2}{|c|}{ (\% of all) } \\
\hline 1943 & 23,149 & 0 & $(0.00)$ & 23,149 & $(100.00)$ \\
\hline 1944 & 26,319 & 0 & $(0.00)$ & 26,319 & $(100.00)$ \\
\hline 1945 & 27,195 & 0 & $(0.00)$ & 27,195 & $(100.00)$ \\
\hline 1946 & 30,454 & 35 & $(0.11)$ & 30,419 & $(99.89)$ \\
\hline 1947 & 28,963 & 1,584 & $(5.47)$ & 27,379 & $(94.53)$ \\
\hline 1948 & 28,471 & 2,023 & $(7.11)$ & 26,448 & $(92.89)$ \\
\hline 1949 & 27,493 & 2,493 & $(9.07)$ & 25,000 & $(90.93)$ \\
\hline 1950 & 27,246 & 4,070 & $(14.94)$ & 23,176 & $(85.06)$ \\
\hline 1951 & 26,703 & 6,815 & $(25.52)$ & 19,888 & $(74.48)$ \\
\hline 1952 & 27,583 & 10,520 & $(38.14)$ & 17,063 & $(61.86)$ \\
\hline 1953 & 27,752 & 15,658 & $(56.42)$ & 12,094 & $(43.58)$ \\
\hline 1954 & 27,429 & 17,142 & $(62.50)$ & 10,287 & $(37.50)$ \\
\hline 1955 & 27,805 & 21,403 & $(76.98)$ & 6,402 & $(23.02)$ \\
\hline 1956 & 27,930 & 24,498 & $(87.71)$ & 3,432 & $(12.29)$ \\
\hline 1957 & 27,525 & 26,067 & $(94.70)$ & 1,458 & $(5.30)$ \\
\hline 1958 & 27,428 & 27,179 & $(99.09)$ & 249 & $(0.91)$ \\
\hline 1959 & 27,847 & 27,697 & $(99.46)$ & 150 & $(0.54)$ \\
\hline 1960 & 27,177 & 27,076 & $(99.63)$ & 101 & $(0.37)$ \\
\hline 1961 & 27,378 & 27,378 & $(100.00)$ & 0 & $(0.00)$ \\
\hline 1962 & 27,246 & 27,246 & $(100.00)$ & 0 & $(0.00)$ \\
\hline 1963 & 27,419 & 27,419 & $(100.00)$ & 0 & $(0.00)$ \\
\hline Overall & 576,512 & 293,303 & $(51.41)$ & 280,209 & $(48.59)$ \\
\hline
\end{tabular}

Note: An individual is treated if the schooling reform had been implemented in the childhood municipality of residence by the year the individual turned age 14, and non-treated otherwise. 


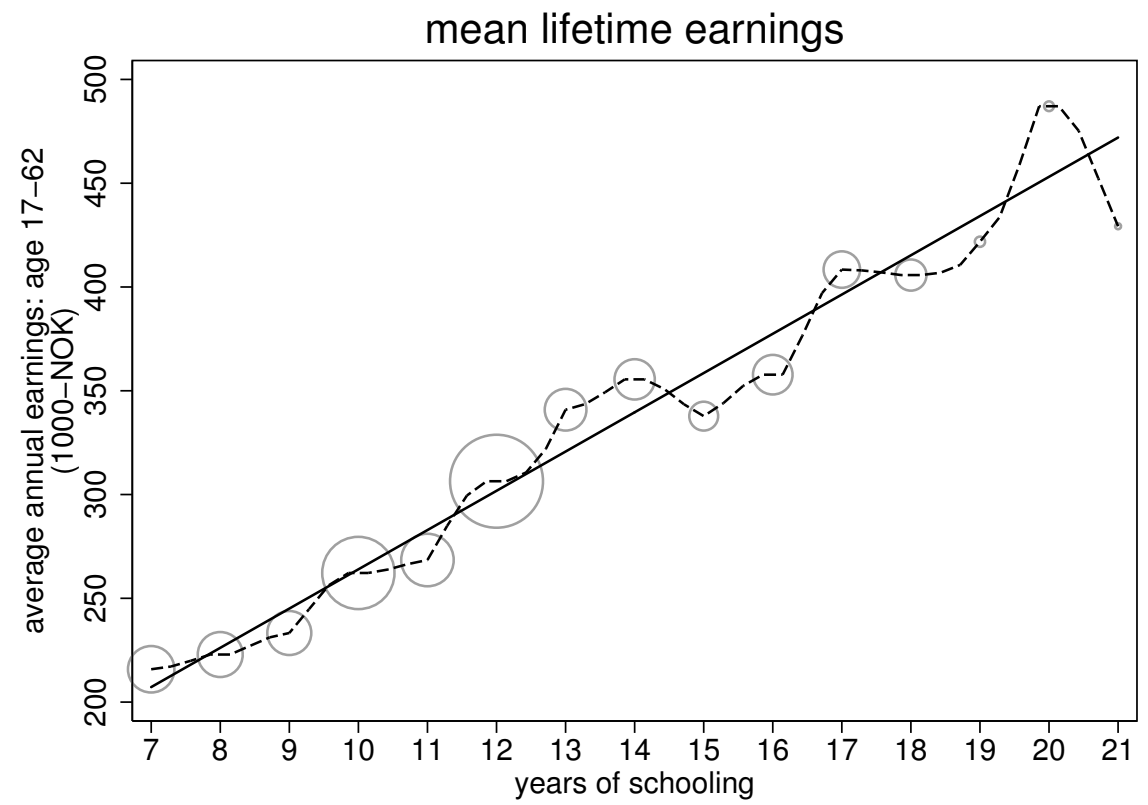

Figure A.1. Functional form of relationship between earnings and schooling

Note: This figure displays (i) predictions from a local linear regression of years of schooling on average annual earnings over ages 17-62 (stippled line), (ii) prediction from a linear OLS regression of years of schooling on average annual earnings over ages 17-62 (solid line), and (iii) the distribution of years of schooling in the full sample (area of round circle). 

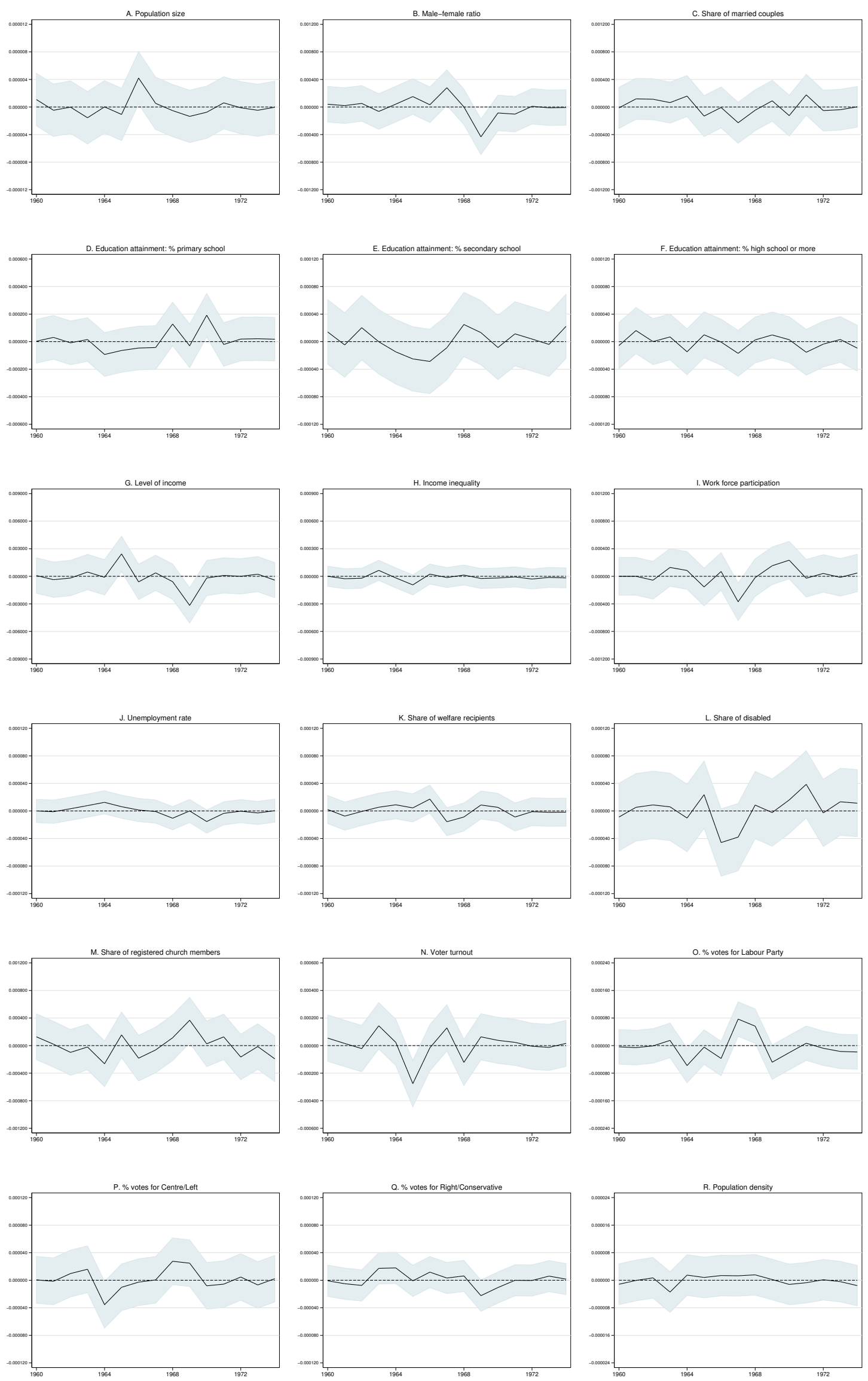

Figure A.2. Reform implementation by3 2 aseline municipality characteristics

Note: We regress an indicator of timing of school reform on baseline municipality characteristics (measured in 1960) interacted with time dummies, controlling for municipality fixed effects (see equation 8). The figures plot interaction terms, with coefficients 


\section{A.2 Summary of the Norwegian tax and pension systems}

As in most OECD countries, the Norwegian tax system is progressive through deductions and surtaxes. Important features of the Norwegian tax system include a basic flat tax rate of $28 \%$ on labor income, a series of progressively increasing surtaxes at different income brackets, a basic income tax deduction that further increases the progressivity, and finally, a social security contribution tax on labor income. While the basic structure of the Norwegian tax system has remained unchanged over the past decades, there have been considerable changes in both the surtax rates, tax brackets, and deductions over time. Moreover, the Norwegian tax system has become less progressive through a series of policy reforms over the recent decades. These features provide considerable variation in both average and marginal tax rates over time, as illustrated in Figure A.3.
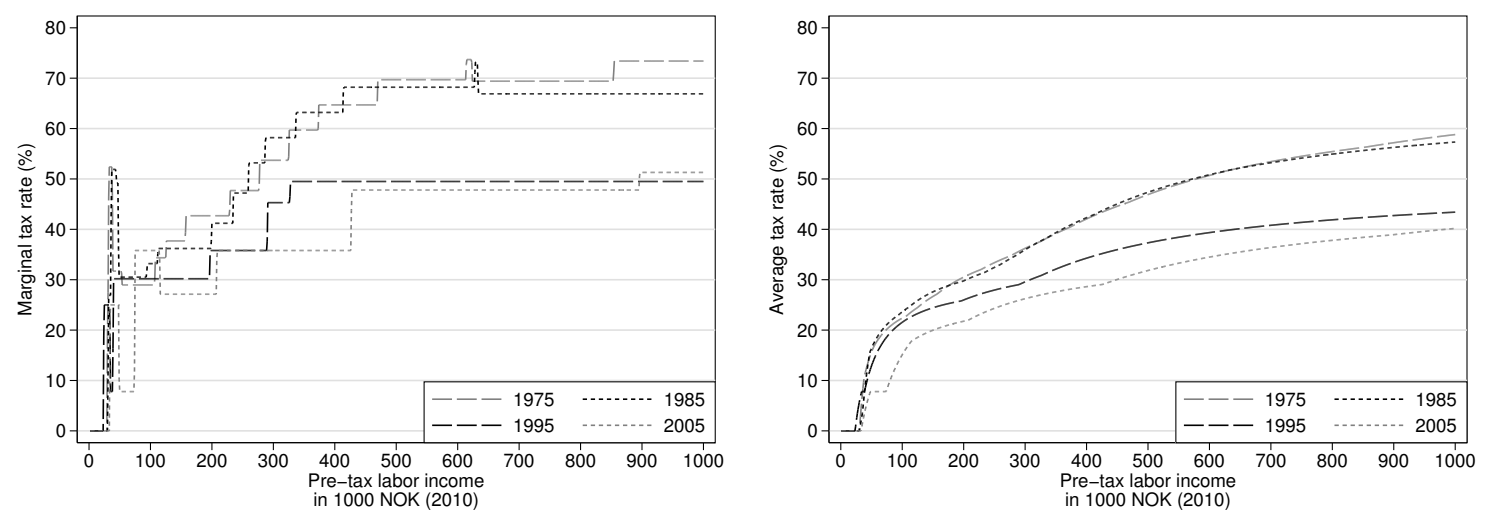

(a) Marginal tax rates

(b) Average tax rates

Figure A.3. Marginal and average taxes on labor income in Norway

Note: Graphs (a) and (b) plot marginal and average rates, respectively, for single wage earners. We take into account progressivity of taxes and basic deductions for labor income. Information on tax rules is taken from SSB (1975, 1988, 1994) and Skatteetaten (2010).

In accordance with the Norwegian National Insurance Act (Folketrygdloven), all Norwegians are entitled to public pension upon retirement. The pension amount depends on an individual's earnings history from age 16 to retirement. Although the mandatory retirement age is 67 , about $80 \%$ of Norwegian workers are entitled to receive early retirement benefits beginning at age 62 (Hernaes et al., 2013). Based on individuals' earnings histories, we compute their pension entitlements and after-tax pension income. Details on the pension system can be found in AID (2009) and NAV (2013), while tax rates on pension income are described in SSB 1975, 1988, 1994) and Skatteetaten (2010). 